25. 高分解能 MRI における Matched Bandwith シーケンス・Fine Reconstruction $の$ 有用性

大垣市民病院

○丹羽文彦・遠藤斗紀雄・高木 等・岩田成真・金森勇雄 今回我々は，MRIに抢ける従来法の撮像パラメータを変化させる ことなく, 高 $\mathrm{S} / \mathrm{N}$ 比が実現できる Matched Bandwidth (MBW) と，高分解能が可能な Fine Reconstruction (FR) を使用する機会が 得られ, 従来法, $\mathrm{MBW}, \mathrm{FR}, \mathrm{MBW}+\mathrm{FR}$ の各シーケンスについ て, $\mathrm{SE}$ 法による $\mathrm{S} / \mathrm{N}$ 比， FE 法による $\mathrm{S} / \mathrm{N}$ 比， SE 法による $\mathrm{MTF}$ の測定し, 比較検討を行った. $\mathrm{S} / \mathrm{N}$ 比については, 従来法に比し, MBW は高い值を示し, FR は低い值を示し, MBW+FR は同等か, 高い値を示す傾向にあった.MTF については, 従来法に比し, MBW はやや低い値を示し, FR は高い值を示し, $\mathrm{MBW}+\mathrm{FR}$ は同等か, や や高い值を示寸傾向にあった。

\section{6. 值腸内挿入コイルの評価}

三重大学医学部附属病院

東 純子・平松奈々・荒木昭信

〔目的〕直腸内挿入コイルの空間分解能, 感度分布測定及び, 臨床 例を報告する〔使用機器〕1.5T SIGNA，性能評価用多目的ファン トム, 自作テストチャート $(0.4,0.3 \mathrm{~mm} \phi 1 \mathrm{p}), コ イ ル=$ MEDRAD $\mathrm{BPX}$ 使用時は約 $40 \phi \times 80 \mathrm{~mm}$ ，挿入時は約 $15 \mathrm{~mm} \phi$ 〔方法〕 スラ イス厚 $3 \mathrm{~mm}$ 一定, FOV 160，120，80 mm で，空間分解能を測定し た。 $0.5 \mathrm{mmlp}$ 以下は，自作テストチャートを用いた。感度分布は FOV $120 \mathrm{~mm}$ で行った. 撮像条件, $\mathrm{SE}$ 法, $\mathrm{TR}=400, \mathrm{TE}=20,256 \times$ 192，256×256，2NEX 〔結果，結論〕空間分解能は FOV 160， 120 $\mathrm{mm}$ で0.75 mmlp, FOV $80 \mathrm{~mm}$ で0.4 mmфlpであった. 感度分布 （信号の最大値が半分に成る深さ）は短軸方向 $13 \mathrm{~mm}$, 長軸方向 $12 \mathrm{~mm}$ であった。臨床上は $30 \mathrm{~mm}$ まで充分な信号強度がある. 対象部位は前 立腺，子宮頸部，䧛胱後壁下部などである.

\section{座長集約}

演題 $22 \cdots$ 腰椎矢状断 T2 強調画像で saturation pulseにより wraparound artifact 除去を試み, 画質評価を行なった. 装置, 診断 目的等の相違のため最適な artifact 除去法を一概に断定はできない が，本発表のように各施設で最適除去法を調べることは必要である.

質問 (座長) 1) TR 延長してT2 を強調させるためなら，現 行の TR でフリップ角度を小さくする方法もあるが可能か. 2) 視覚 評価のかわりに contrast-to-noise ratio を使用してはどうか. 3）患 者の信号強度評価は，值が相対的なので不明確ではないか。

答（演者）1）フリップ角度は可変不能.2）検討する.3）レシー ブゲイン等を一定にしたので問題ない.

演題23ㄱフリップ角度が120度で spoiler と saturation pulse の加 わったSE法によって肝腫㿠の dynamic studyを行ない, 従来の gradient echo 法と比較した. 演者も言うように時間分解能に関して は十分でなく,さらなる短時間の撮像法の開発を期待する。

質問（古市…豊川市民病院） 1）TR $180 \mathrm{sec} に し た$ 理由は何 か.2）フェーズェンコードの削減(長方形マトリックスまたは長方形 FOV) は行なったか. 3) Time intensity curve は求めたか.

答 （演者）1）SN 比とスライス枚数を考虑して決定した. 2) 長 方形マトリックス $50 \%$ および長方形 FOV 60〜 65\%のエンコード削 減率である．3）装置の制約ならびに時間分解能が十分でないために 求めていない.

演題24‥静岡県内の MRI 装置に扔ける運用状況，検査方法等，多 項目にわたって調べ検討したものである.大変興味深い結果を報告し ており，西部地区勉強会の次なる研究成果を期待する次第である.

質問 (座長) 本アンケート結果をもとにして, 実際に各施設に扔 いて改善されたことはあるか。

答（演者）検討中である。

演題 $25 \cdots 256 \times 256$ の画像データを Raw デー夕領域において 512に補間したこと及び受信带域幅を変化させたことに対する画質評 価である．質疑応答で「帯域幅を広くする手法」と演者は述べたが， 内容は带域幅を狭くしたようにうかがえる. 次の報告において手法の 内容を明らかにされることを期待する。

質問 （杉浦…聖霊浜松病院）受信周波数带域は，1）可変である か. 2) 適応部位はどこか. 3) Chemical shift artifact の影響はある
か. 腹部においてどうか.

答（演者）1）不可能である.2）広带域のため動きの少ない頭部 で使用した，3）影響はある。腹部において有用性が低い.

質問 (座長) Raw データ補間による画像データ量の増加, 画像 再構成時間の延長の問題はどうか.

答（演者）デー夕量は 4 倍，再構成時間は 3 倍になる。

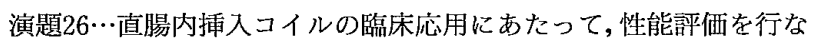
い適応範囲を具体的に示したものである. 臨床応用にむけて, 今後の 研究を期待する。

質閭（座長） 1）コイルの侵襲性はどうか.2）空間分解能が理論 值と異なることがあったのは,ファントムの精度に起因するか.3）直 腸内挿入コイルに扔いてのみ診断可能であった場合はあるか。

答 （演者）1）苦痛, 羞恥心のため非侵襲的と言えない. 2) 精度 による，3）ないが，診断が容易になった。

質問（山田…東海市民病院）サーフェイスコイルの信号不均一 性を改善する方法はあるか.

答 （座長） 信号の最大值と最小値を除く方法, サイン波の信号減 裹に対して重み付けをする方法がある。

被曝

座長 倉西 誠. (富山医科薬科大学医学部附属病院)

27. 頭頸部の血管内手術における術者および患者の被暴線量 富山医科薬科大学附属病院

○新谷光夫・熊谷道朝・小西 稔・倉西 誠

頭頸部血管の塞栓, 拢張等をカテーテルを用いて行う脳血管内手術 では拡大透視とDSA 撮影の多用により術者と患者の被曝線量は大 幅に増大している。今回, 長時間の血管内手術を要した 8 症例につい て TLD 素子を用いて術者 7 箇所, 患者 5 䉯所の被嚗線量を測定し た. 術者に扔いて実効線量当量は最大 $0.45 \mathrm{mSv}$ を示し, 眉間の線量 当量は最大 $0.49 \mathrm{mSv}$ であった。 また, 頸部では钼部プロテクター着 用により被曝線量を $1 / 7 \sim 1 / 30$ に軽減できた。

患者において眉間の線量当量は最大 $136 \mathrm{mSv}$ を示した。 また，側方 向撮影時, X線管球側に位置する右側頭部で最大 $3,656 \mathrm{mSv}$ を示し た.

28. 診断領域の $X$ 線における患者被曝線量の推定 第 3 報

（各種発生方式における出力波形の検討）

藤田保健衛生大学衛生学部

○藤井茂久・鈴木昇一・浅田恭生・折戸武郎

東海医療技術専門学校

嶋崎宏紀・稲垣信司・山口幸三

〔目的〕 X線診断に扔ける被嚗線量は ICRP pub. 33より定電圧形 発生装置に扔ける線量を推定することができる，そこで，総ろ過を一 定にしたときのX線発生方式による出力波形と照射線量の関係を検 討したので報告する。

【方法】各装置の総ろ過を $3.0 \mathrm{mmAl}$ に統一して, 出力波形, 半価 層, 管電圧, 管電流, 空中線量等を测定した。

〔結果〕出力線量は 2 ピーク形, 単相インバータ, 12 ピーク形, 三 相インバータ, 定電圧形の順に高い值を示した. 2 ピーク形, 12 ピー ク形, 定電圧形では出力波形に, インバータ方式では出力波形, イン バー夕周波数, 入力電源に依存した。これょり, 定電圧形発生装置以 外では出力波形の把握が必要と思われる。

29. 診断領域X線における患者被曝線量の推定 第 4 報

(インバータ式X線装置における出力波形の検討)

東海医療技術専門学校

○稲垣信司・嶋崎宏紀・山口幸三

藤田保健衛生大学衛生学部

鈴木昇一・藤井茂久・浅田恭生・折戸武郎

〔目的〕医療被嚗を解析する基礎的な研究としてインバー夕式X 線装置の出力波形と線量の関係を分析した.

〔方法〕 入力電源を異にする装置 (単相入力 7 台と三相入力 8 台) のX線出力と出力波形を测定した。

〔結果及び考察〕装置毎でX線出力, 出力波形のバラツキがあり, 入力電源やインバータ周波数などにより出力波形の脈動が変化した. 三相入力インバー夕式X線装置と比較すると, 単相入力インバー夕式 $\mathrm{X}$ 線装置の出力波形は脈動が大きく, X線出力が少なくなった. 出力 